\title{
Unfulfilled Vocations in Contemporary American Fiction
}

\author{
Hywel Dix
}

Faculty of Media and Communication, Bournemouth University, Poole, UK

Corresponding author: Hywel Dix, Faculty of Media and Communication, Weymouth House, Talbot Campus, Fern Barrow, Poole, Dorset BH12 5BB, UK.

HDix@bournemouth.ac.uk

Tel. 01202966679

Orcid ID: 0000-0002-3584-5199

Word count: 8,126

Biographical note: Hywel Dix is Principal Academic in English and Communication at Bournemouth University. He has published extensively on the relationship between literature, culture and political change, most notably in Postmodern Fiction and the Break-Up of Britain (Continuum, 2010) and Multicultural Narratives: Traces and Perspectives, co-edited with Mustafa Kirca (2018). His wider research interests include modern and contemporary literature, critical cultural theory, authorial careers and autofiction. His monograph about literary careers entitled The Late-Career Novelist was published by Bloomsbury in 2017 and an edited collection of essays on Autofiction in English was published by Palgrave in 2018. 


\section{Unfulfilled Vocations in Contemporary American Fiction}

This paper analyses the representation of unfulfilled creative vocations in contemporary American fiction through the lens of career construction theory, which emerged after the 2007 economic crisis when large numbers of people sought new forms of vocational guidance to suit the altered conditions of their working lives. It argues that during the same period, an increasing number of American novelists started to portray changing or unfulfilled creative vocations in their fiction, as a response to the same overall changes in American society. This means that career construction theory and the fictional portrayal of frustrated vocations have a common historical origin, so that the former can usefully be applied to our interpretation of the latter. The paper undertakes such work by applying specific components of career construction theory to interpretation and analysis of particular texts. Specifically, it applies Mark Savickas's idea of meta-reflection to a reading of Joshua Ferris's novel Then We Came to the End (2007); John Holland's concept of vocational personality to analysis of Siri Hustvedt's The Blazing World (2014); Peter Mcllveen's notion of exo-theme, or compromise, to Meg Wolitzer's novel The Interestings (2013) and Kobus Maree's use of career case studies to Jennifer Egan's A Visit from the Goon Squad (2010). Overall it argues that career construction theory is a potentially fertile body of work capable of informing our understanding of the fictional portrayal of creative vocations in new and innovative ways.

Keywords: career construction theory; vocations in fiction; Ferris, Joshua; Hustvedt, Siri; Wolitzer, Meg; Egan, Jennifer

\section{Introduction}

This paper proposes that a new way of thinking about creative vocations is enabled by bringing the body of work known as career construction theory into the domain of contemporary literary research. It takes as its starting point the fact that the period of deindustrialisation in western economies during the late twentieth century gave rise to a whole series of changes in people's vocational behaviours; changes which accelerated rapidly after the economic crash of 2007. Career construction theory emerged in the 
wake of these developments, as an increasing number of people sought new forms of vocational guidance to better equip them for the rapidly changing nature of their working lives. In contemporary American fiction, these changes have given rise to an increasing tendency among writers to portray the frustration or failure to fulfil a series of creative hopes, dreams and ambitions on the parts of their protagonists, in the light of an unprecedented restructuring in the make-up of the economy, culture and society.

To some extent the emerging theme of unfulfilled vocations in American writing and the practice of career construction theory as a new form of vocational guidance have common origins. By bringing career construction theory to bear on the interpretation of how unfulfilled vocations have been portrayed in fiction, this paper argues that career construction theory is an innovative body of work capable of telling us much about that developing theme in recent literature, and perhaps about contemporary authorship more generally. Before moving on to apply the insights of career construction to analysis of specific fictional portrayals of different vocations, it is therefore necessary to identify the principal elements of career construction in theory.

\section{Defining Career Construction Theory}

Prior to the twenty-first century, career guidance counselling depended heavily on using a range of quantitative data to match individuals and roles. Psychometric profiling, databanks, scores on aptitude tests and the ranking of elements in career interview forms were among the most commonly used varieties of evidence that were deployed. Larry Cochran (1997) suggests that with the altered patterns of work that emerged in the late twentieth century these numerical metrics are 'limited' if used without recourse to other forms of data. ${ }^{\mathrm{i}}$ More specifically, such metrics are incapable of dealing with either the natural complexity or the emotional conditions that arise out of the simple fact of being human. Statistical evidence might reveal the kinds of role or environment in 
which an individual has operated successfully in the past; but will not be able to indicate what kind of new or altered role will offer them satisfaction in the future because naked statistics alone do not address the question of meaning and hence of value. This is where the importance of vocation comes in. Knowing what precisely about a particular role, relationship, workplace or environment has made an individual feel fulfilled is necessary if other roles are to provide a similar sense of emotional satisfaction in the future, even across outwardly different kinds of work. Thus Cochran suggests that overreliance on statistical measures in vocational guidance has the effect of losing sight of the emotions, values and commitments that make the individual who they are, treating them as 'not so much a person as an organism with attributes. ${ }^{\text {ii }}$ Because what makes one person feel enriched, valued, satisfied and ethically sound will not be the same for another person, those same bearers of meaning and emotional value cannot be reduced to statistics and are better elicited in conversation, dialogue and narrative.

Career construction was given fresh impetus by the rapid changes that have come about in people's working lives since the worldwide economic crisis of 2007. Within literary studies, critical and theoretical discussions of fictional responses to the financial crisis have so far taken one of three forms: those that focus on the role of toxic individuals; ${ }^{\text {iii }}$ those that focus on the human cost of dispossession through one or more traumatic events occasioned by economic disempowerment; ${ }^{\text {iv }}$ and those that focus on the systemic structures through which the recession was felt - typically either the closing of a business or the repossession of a family home. ${ }^{\mathrm{v}}$ In other words, critical analyses of responses to the global recession have again tended not to consider changing vocations as distinct from professional careers per se.

Drawing on the work of Cochran, Savickas (2011) proposes a new form of career counselling based on telling and listening to life stories. The mainly quantitative 
methods used in earlier forms of vocational guidance are supplemented with a narrative method that is more qualitative in nature. It is a practice whereby individuals construct their own career life stories in narrative; and the counsellor re-narrates them back to the client in slightly altered form so that the latter can 'see themselves in the story. ${ }^{\text {vi }}$ In the process, they view themselves from a slightly new vantage point. This new perspective on their own lives has the effect that they identify themselves not only as protagonist in the life story, but also and more importantly as its author. It thus gives them a sense of agency and control over future directions, empowers them to imagine a new chapter in that story - and by imagining it, begin to write it and so live it. Indeed, it has been argued that the authorial metaphor is so prevalent in career construction theory as to make career construction itself a useful body of work in theorising constructions of authorship within literary research. ${ }^{\text {vii }}$

After its narrative method, the second key element in career construction is the interplay it mobilises between different life stages over the course of someone’s lifespan. Periods of turbulent change seem to offer themselves as neat markers of temporal transition between one role and another and hence between one life stage and another. Peter McIlveen and Wendy Patton have argued that a person has the potential to embody a number of different possible selves, speaking and acting from what they call multiple different 'I-positions. 'viii In their account, cultivating the capacity to imagine oneself occupying the greatest possible number of different I-positions is in large part the aim of career counselling, since for an individual to do so by definition means imagining occupying multiple different roles and hence keeps the greatest possible number of vocational choices in play.

One implication of this sense of multiplicity is that career construction practitioners reject the notion of a single, unified essential self and replace it with the 
idea of a 'vocational personality. ${ }^{\text {ix }}$ The elucidation of a vocational personality entails establishing a 'life theme', that is, a series of values, aspirations and sources of meaning by which individuals define themselves as characters in their life story and which once identified as such can be used to guide the process of making vocational decisions during times of change. ${ }^{\mathrm{x}}$ The life theme is typically something fundamental such as 'helping others' or 'fighting injustice' rather than a specific career role. ${ }^{\text {xi }}$ The business of career construction is then to identify means of fulfilling those aspirations - which might include the selection of a corresponding career or professional role, but might equally involve identifying roles and activities that can be pursued in addition to or alongside the working life itself.

Clearly, therefore, the question of a vocational personality is a complex one. On the one hand, the insight that a person's sense of being is constructed in dialogue with social relationships overhauls simplistic notions of a timeless self. On the other, the notion of a life theme posits a nucleus of core values that, though they vary with time and place, provide a meta-level consistency according to which a person’s actions, motivations and vocational choices can be understood. Any attempt to map transformations in the sense of self as it enters a new vocational role must avoid the pitfall of positing one aspect of the vocational self as somehow more authentic than the others. For this reason, the question of the self bears directly on how we understand life stages. Once we have established that there is no single version of the self that is more authentic than any other, it becomes necessary to realise also that the different Ipositions occupied at different times are not necessarily successive, and that a person might occupy and narrate from multiple different I-positions at the same time. This in turn requires that we overhaul the model of different life stages succeeding each other in a simple linear fashion, and suggests instead that life stages are porous, open ended, and 
prone to overlap with each other. Just as a person might occupy many different Ipositions at once, so too they may be in several different life stages at the same time.

All of this points to career construction as employing a dynamic interplay between two different time frames within a professional life. A career narrative is rendered coherent when the different roles experienced within it are all considered both in the specificity of roles or activities experienced during particular periods, and by identifying what (if any) common threads run through them all, despite significant apparent diversity and divergence. It is therefore less useful to identify life stages as specific periods of time within a given life course, than as the network of experiences and relationships that exist in periods of time, plus the ascription of meaning and value to them by the person in question. Often finding out what provides a sense of fulfilment and purpose evokes a sense of commonality for someone across seemingly different roles in their lives. This is why the novels discussed below can be fruitfully examined through the lens of career construction theory: they too deploy the same interplay between different life stages in order to explore what happens to people’s vocational callings when the circumstances in which those vocations developed begin to change.

This focus on changing circumstances brings up the third component of career construction theory (after the narrative method and the interplay between different life stages): its use of meta-reflection. At times of transition, the vocational personality can appear to come under significant stress, which is why Savickas proposes identifying aspects of the self that remain consistent no matter what the changed environment. In the face of such changes, re-examining past challenges and how these were overcome provides a rich opportunity for doing so in the future. Moreover, Savickas argues that using past behaviours to inform future actions is valuable because it activates a degree of what he calls 'awareness of awareness. ${ }^{\text {xii }}$ This involves reconsidering past decisions, 
actions and interventions to identify not merely what actions were taken, but more importantly, why these decisions were taken and whether or not they were effective. Meta-reflection is not simply a question of trying to repeat past actions or recover prior circumstances. It is a matter of using the experiential process of evaluating past decisions to inform how new challenges are addressed in altered circumstances. That is, the purpose is not to restore a prior state of affairs but actively to construct a new one.

The following sections analyse four different novels through the lens of career construction theory: Joshua Ferrris, Then We Came to the End (2007); Siri Hustvedt, The Blazing World (2014); Meg Wolitzer, The Interestings (2013); and Jennifer Egan, A Visit from the Goon Squad (2010). These texts have been selected for two reasons: first because they are specific examples of the more general tendency in American fiction of the past two decades to portray the frustration of creative vocations in the wake of a number of changes in the structure American society. Secondly, they each include particularly prominent instances of the core components of career construction theory discussed above. Thus the relationship that emerges between theories of career development and critical analysis of contemporary fictional works portraying changing vocations is a fundamentally dialectical one in which each adds something useful to what we know about the other. Existing discussion of so-called 'crunch lit' has failed to appreciate this vocational component. ${ }^{\text {xii }}$

\section{Vocation and Meta-reflection in Then We Came to the End}

Much analysis of Joshua Ferrris's 2007 novel Then We Came to the End adheres to the varieties of critical reaction to the global economic crisis outlined above. Ruth Maxey interprets the novel as an expression of wider anxieties about American national identity and cohesion, arguing that it 'exposes as a pretense the official language of togetherness and certainty in corporate America' since 'the collective pronoun of national belonging 
is defamiliarized, broken down, and hollowed out: semantically, socially, and existentially.' ${ }^{\text {xiv }}$ Alison Russell sees it as a war-on-terror novel which dramatises 'post9/11 office workers' need for safety in numbers' and thereby 'signals a shift from older examples in the genre of workplace fiction, reflecting as well the changed environment of American office places. ${ }^{, x v}$ Interpreting the novel using the methods of career construction incorporates elements of these approaches while also drawing attention to the durability of vocational behaviour as such.

As Maxey notes, Then We Came to the End is narrated in a second person plural ('we') which never crystallises into the singular 'I' that it nevertheless implies. Its tragicomic setting of an advertising agency in which the executives are being made redundant one by one while simultaneously collaborating with and competing against each other is a portrayal of both the human cost of the credit crunch and the systemic structures that made it possible. In this way, identifying the narrating 'I' is deferred until the very last sentence: 'We were the only two left. Just the you of us. You and me.' xvi By reaching out finally to a generic reader ('you'), the individual narrator is retrospectively posited as a typical representative co-worker of any given reader, so that any such reader can be implicated in the narrative and the workplace is analogous to any workplace. Ferris's use of a posited generic narrator to imply a relationship with the reader recalls what Raymond Williams wrote about the (generic) reader of Dickens's Hard Times (1854): that the construction of readers typical representatives of their social group militates against precise specification or individual identity so that they can be used to forge a symbolic unity transcending the social conflicts of the Industrial Revolution. ${ }^{\text {xvii }}$ In other words, it is a form of Fredric Jameson's political unconscious: symbolically resolving conflict through narrative. ${ }^{\text {xviii }}$ Since Then We Came to the End is also set during a period of dramatic economic turbulence and socio-political conflict, 
the same comments could be applied to it. It too can be seen as Ferris's recourse to the political unconscious of narrative, through the attempt at resolving the social contradictions in the society where he was writing.

If this were the whole story, it would be difficult to interpret Then We Came to the End as much more than an impotent form of critique or at best a form of blank satire. However, it can be interpreted as doing more than simply offering to foreclose those socio-economic conflicts for two reasons. First of all, creative vocations as such are shown to be resilient even in the face of economic challenge. Creative vocations abound in Then We Came to the End, from Benny the raconteur; to Jim the Cubs fan; Genevieve who is a potential fashion model; Dan who is a painter of highly stylised designs; Don who works on screenplays in his spare time; and Hank who is writing a novel. These characters are all part of the implied 'we' of the novel, the missing particular ' $\mathrm{I}$ ' of which is never specified. As such, they can be interpreted as representing the tension that exists between individual voice and collective expression.

To some extent there appears to be safety in numbers, but to be subsumed within the collective risks cutting off individual forms of artistic creation. This conflict is expressed when, drawing attention to the fact that advertising executives refer to themselves as creatives and to their advertising copy as creative, Ferris summarises their vocational work by describing them as 'creative creatives creating creative creative. ${ }^{\text {xix }}$ More than simply satirising commercial jargon, this anguished juxtaposition of different definitions of creative invites us to ask whether the creative act is something we produce and control, something that exists entirely outside us, or something in between; and thereby embodies the novel's central dynamic question of how the individual relates to the group in the fulfilment of a creative vocation. 
Secondly, as this example suggests, although the novel is comical it is also serious. The final section, its coda, leaps forward five years to a time when the head of the department, Lynn, has died of cancer and when her whistleblowing colleague Tom has joined the army rather than go to prison for industrial espionage - only to be killed in Afghanistan. This temporal shift is out of keeping with the mainly linear temporal structure of the novel. It reveals that within five years everyone else had moved to other organisations and forgotten their old work place relationships. However, career construction theory can be used to interpret the novel in a way that avoids acquiescing in a sense of powerlessness. All of the characters come together one last time during the coda for a public reading of Hank's novel. The final revelation - that the sections of Then We Came to the End about Lynn's illness and death are fictional extracts from that novel - elevates the text onto a metafictive plain that recalls the meta-reflection of Savicaks's career construction theory. When people make vocational decisions, the whole purpose of meta-reflection is to reconsider past decisions, actions and interventions, identifying what they were trying to achieve, evaluating the extent to which the objective was fulfilled, and considering what barriers or constraints prevented further success. Meta-reflection creates a cyclical pattern of symbolic behaviours that can be re-applied when subsequent decisions are made and evaluated. It thus enables individuals to consider how they make decisions: reflecting, as it were, on the process of reflection.

Bringing a metafictive device such as Hank's novel into Then We Came to the End creates a depiction of precisely this form of meta-reflection. The result is that beyond the blank parody or foreclosure of political conflict that would otherwise be associated with this kind of satire, using career construction theory to think about how vocational decisions were made in the past and how these might be re-applied in the 
future provides a newly critical perspective on the context in which the novel was written, in which people's work and life patterns had fundamentally changed. The metafictive technique used by Ferris can then be interpreted through the lens of career construction theory as a portrayal of the resilience of vocational impulses in the face of changing structures of work.

\section{Vocational Personality in The Blazing World}

As with Ferris, Siri Hustvedt's 2014 novel The Blazing World employs a retrospective narrative in an effort to measure the progress of a specific artistic vocation. In the American tradition that dates from Sleepy Hollow, Moby Dick and beyond, The Blazing World wades through different levels of textual fragment: the introduction by fictional ‘editor’ I.V. Hess; imaginary excerpts from reviews of art exhibitions; interviews with friends and colleagues of the main artist depicted; transcripts of interviews and statements purportedly made by relatives after the deaths of the principal characters; and fictionalised excerpts from those artists' notebooks. Unlike Then We Came to the End, however, these textual layers are not compounded simply to enable a degree of critical meta-reflection on an existing state of affairs. Instead Hustvedt portrays different aspects of a single vocational personality and explores how a sense of selfhood can be changed when either the environment or social relationships in which the self is involved are changed. Indeed, whereas several other commentators have provided detailed textual exegesis of The Blazing World, ${ }^{\mathrm{xx}}$ the main purpose in including it in the present discussion is to highlight precisely this depiction of a multi-faceted vocational personality.

Hustvedt appears to believe that women have been marginalised as artists and intellectuals; and creates a fictional artist, Harriet Burden, to challenge that marginalisation. The different textual fragments supposedly compiled by Hess gradually 
cohere to narrate a hoax played by the character Burden on the male-dominated art world of New York in the 1990s and 2000s: hosting three different exhibitions, and attributing them to the work of three so-called 'masks' (i.e. other artists). Because the masks are all men, she launches an experiment to explore if the reaction to the work varies according to the gender of the artist. The first of these, Anton Tish, is a young naïve who is easily manipulated but who has his own dream of becoming an artist damaged by the encounter with the abrasive Burden and disappears from New York altogether. The second, Phineas Q. Eldridge, is a bi-racial burlesque performance artist who is very happy to concede that the artist was Burden. However, the third, Rune, denies this utterly. He betrays Burden by taking sole credit for a performance exploring altered gender and sexual roles that they devised together. Worse, his death in a separate performance piece makes his claims impossible to either confirm or refute; his very name pointing to the indecipherability of so many different forms of inscription and hence of truth-claims. Through these masks, and the personae and textual excerpts associated with them, Hustvedt continually poses the question: what is real? and thereby interrogates the notion of truth. At the same time, the question of reality (or at least, of how it is perceived) is intimately bound up with her character Burden's vocation as both an artist and a woman. The whole experiment explores how the work of this female artist is perceived when it seems to have been created by people of different races and genders, compared to how it is received when it announces the status of its female creator as such.

Although distinguishing between more and less desirable vocational pathways is clearly important for career counsellors, the purpose of career construction is not necessarily to distinguish between true and untrue perceptions of reality. It is more a matter of using perception to shape and clarify the nature of a vocation itself. Savickas 
explains that in a career guidance interview, he asks participants to provide three childhood memories and weave them together into a story or sequence. The point of this is not to ascertain whether or not the contents of those memories are verifiably accurate as 'historical facts. ${ }^{\text {xxi }}$ It is more about identifying what values the individual assigns to the memories, and how such values can be used to elucidate a new degree of selfknowledge for the individual (even if the content of the memory turns out to be misremembered or inaccurate). However, merely naming the feelings or behaviours projected onto the past from the standpoint of the present (as per Starobinski's 1966 definition of 'nostalgia') is not the end point in itself. ${ }^{\text {xii }}$ A constructivist approach to life stories extends the use of past experiences by exploring how somebody's memories can be used as the raw material for writing the next chapter in their life story and hence enables them to begin actively constructing - as opposed to merely naming or reflecting on - a potential future. The purpose of career counselling after all is to empower individuals to make meaningful change in their lives by imagining a future that is both realistic and desirable, and taking practical steps to create that future.

Within The Blazing World, the reality Harriet Burden wants the art-viewing public to perceive differs from the reality that Rune attributes to the public narratives of the exhibition. Each of these is created by Hustvedt so that neither can be said to be any more 'real' than the other. But this does not mean it is impossible to distinguish between them in a cognitive sense. According to Kobus Maree, the question of reality is better understood when applied to the vocational guidance sphere as a matter of clarifying different levels of perception than as a basic distinction between true and untrue, which may in any case be illusory. To Maree, if our perception of reality is mainly sociological then it arises out of our relationship with other people at the 'interpersonal' level; whereas if it is considered mainly psychological then it is produced 
within a single psyche at the 'intra-individual' level. ${ }^{\text {xxiii }}$ In effect, The Blazing World portrays a conflict between these two levels of perception. Rune's (male) account of the production of the work and his claim to ownership over it are sociologically positioned to appear more plausible than Burden's female account of the work driven by her own psyche. As a result he achieves not only artistic recognition but also considerable wealth, power and status in the booming art world of pre-recession New York. These are the things that are shown to have been unavailable to Burden.

Thus the multiple kinds of textual object created by Hustvedt bear testament to how reality is constituted and perceived in an affective and meaningful way that moves beyond the simple question of real versus non-real. The masks, that is, the different avatars of Burden all function differently in different social situations, while also contributing equally to the overall experiment. It investigates the notion of a vocational personality; that is, the question of how far a person's sense of self seems to differ when viewed either from or in an altered artistic, cultural and social position. In the last instance, this experiment applies not just to Burden but also to Hustvedt herself. In her portrayal of the fictional editor Hess's attempt to reconstruct the fragments of Burden's life, Hustvedt includes her own name as an 'obscure novelist and essayist' in a list of fictional authors whose works her character purportedly read. ${ }^{\text {xxiv }}$ In this way, she semifictionalises her status as author and renders her character a further aspect of her own vocational personality. Her vocation is then to shine a light on under-recognised female artists and in the process to critique masculine authority which ultimately also is a form of cultural capital and political power.

\section{The Expression of an Exo-theme in The Interestings}

Like The Blazing World, Meg Wolitzer's novel The Interestings (2013) portrays a number of different human responses to the experience of seeing artistic vocations worn 
down over long years of effort. The eponymous characters are a group of high school students who meet at a summer camp for the artistically gifted during the summer of 1974, and whose lives remain intertwined. During the course of Ethan and Ash's marriage, Ethan's creative aspirations as an animator come to lucrative fruition when his animated series Figland is taken up by a television network. Ash had had an artistic dream of becoming a theatre director, but though she continues to dabble in this it is clear that she is only able to do so because Ethan's name and wealth open doors to her, and that her creative work is tantamount to a vanity project. Jules also once had a specific vocation: becoming an actress. But she gives up on this altogether after one too many failed audition, and re-trains as a psychologist in a low-income area of New York City. Her ongoing friendship with Ethan and Ash is thus profoundly ambivalent, bound up with envy, regret and even anger at their success, which seems to mark such a contrast to her own vocational failure.

It is a commonplace observation that according to the American dream, anyone can achieve anything they want to. But career counsellors are all too aware that in practice this is far from the case. As McIlveen puts it succinctly: 'an individual cannot become, in a career sense, whatever they desire. ${ }^{\mathrm{xxv}}$ There are all sorts of factors that not only enable, but also limit and constrain the range of vocational decisions that are available. These include on the one hand intrinsic factors such as one's natural abilities, educational attainment, experience and aptitude; and on the other hand extrinsic factors such as whether or not one is able to move to different places for work or is tied to specific geographical locations for family, cultural or financial reasons. Some of the factors that appear to make possible the pursuit of particular vocations can at the same time frustrate the fulfilment of them. When this happens, McIlveen suggests, the individual must forge what he calls a 'exo-theme', that is a 'meaningful compromise' 
between the vocational aspiration as it exists in pure unalloyed form and those external factors which are not aspects of the person's self or psyche at all but which nevertheless 'limit' what they can practically do. ${ }^{\text {xxvi }}$ Such a compromise entails the taking of steps that might not enable the complete fulfilment of the original vocation, but can at least be considered somewhat equivalent to doing so.

The Interestings is a case study in exo-thematic compromise. Jules rapidly becomes disillusioned with the corporate greed that surrounds her in New York in the 1980s and 1990s. Noting that powerful corporations have started buying valuable works of art not out of any aesthetic pleasure or even with any intention of exhibiting them to the public but simply as an investment the value of which will increase over time, she thinks: 'in the past people appreciated artwork. Now artwork appreciates. ${ }^{\text {xxvii }}$ The language employed by Wolitzer here bespeaks a wider transformation that has taken place in our understanding of vocational behaviours. The former usage of the word appreciate is a transitive verb. That is, it expressed an active relationship between a subject carrying out the action and the object which is acted upon. The latter usage, by contrast, expresses a loss of transitivity in the relationship in question: people no longer carry out the act of appreciation, which is linguistically transferred to the artwork itself, as if in a largely passive way. Related to this transition from active to passive there is also the distinction between two definitions of appreciate, where the former is about sensory engagement and pleasure while the latter is about accumulation of surplus value as commodity.

Kobus Maree draws attention to the importance of vocational guidance counsellors paying precise attention to the 'first verb’ clients use during career counselling interviews because 'it indicates the kind of action that characterizes the way in which the client absorbs into and connects with' the world. ${ }^{\text {xxviii }}$ Wolitzer's 
juxtaposition of the two uses of appreciate can be understood in just this way. The perception of art as commodity in an inhuman system of exchange contrasts with the pursuit of aesthetic satisfaction for its own sake that had originally been promoted by the original Spirit in the Words camp. This contrast reveals a crisis in Jules's artistic vocation, which in turn opens a distinct perspective on the corporate world of which it is implicitly critical. Using theories of career construction and vocational guidance provides a distinctive way to articulate this critique, especially when compared to the more common theoretical approaches to fictional portrayals of the economic recession, which as noted above tend to focus either on the role of individuals or on abstract structures.

The feelings Wolitzer associates with Jules at this point might imply a desire to return to an earlier set of affairs that is imagined to be somehow more comfortable, or more innocent (which is the implication of Boym's restorative nostalgia). ${ }^{\mathrm{xxix}}$ However, this is not the whole story. Jules resists succumbing to those feelings of wanting to return to an illusory past, and instead must use her understanding of the past to build up a material future for herself. Those life stories are then constructed in and through narrative; more specifically, forms of narrative that start off with the past memories in a person's life story and then transforms them into new chapters in the life narrative.

Jules is unable to fulfil her vocation as an actress, envious of Ethan's artistic success and resentful of the opportunities his wealth creates for Ash. Using Mcllveen's idea of the exo-theme, we can see that only a meaningful compromise will allow her to make her way out of this impasse. Focusing on a role that might not be eye-catching or glamorous but which nevertheless provides a source of meaning and hence legitimacy to her is a necessary step in making such a compromise. Thus she arranges with her husband Dennis to take over running Spirit in the Woods. Following the failure of her 
artistic aspirations comes a compromise in the form of becoming an enabler of the dreams and ambitions of others. With this comes the recognition that: 'It's alright not to be special or spectacular or artistically gifted or even to marry your soul mate. It's alright to be average - most people are. ${ }^{\mathrm{xxx}}$ This combination of an intrinsic interest in creative vocations with extrinsic factors such as her relationship with her husband and the need to earn a living when he is ill can be seen as the achievement of an exothematic compromise. The career constructionist concept of life themes can thus be used as a new way of understanding how vocational behaviours have changed.

\section{Fictional Case Studies in A Visit from the Goon Squad}

In The Blazing World, Siri Hustvedt uses the creation of several different personae to filter diverse aspects of a single central vocational personality, in order to test how far that personality changes when perceived in the context of different relationships and from the standpoint of an altered gender. Wolitzer in The Interestings does almost the opposite, depicting a close-knit group of six different people and exploring how they each respond to the same general challenge: the question of their vocation. The interplay between past and present, and between different life stages, has the effect of contrasting where people thought they were going; and where they end up, which is an inevitable compromise between the two. Ethan's artistic achievement as an animator does not automatically bring a sense of satisfaction and the financial rewards it brings about give rise to new challenges, notably in the way it alters his relationship with his old friends. If his success as an artist brings a sense of fulfilment at all, this is not because it makes him wealthy but because it gives a sense of meaning and creative purpose to his life.

Arguing that the frustration of specific creative visions has become a major theme in American fiction in the twenty-first century, this paper concludes by 
discussing one final example: Jennifer Egan's A Visit from the Goon Squad (2010). In this work consisting of thirteen interlinked narratives, Egan's genre experimentation and technical innovation have been analysed in detail by critics such as Katherine Johnston, who draws attention to its metafictive nature; ${ }^{\mathrm{xxxi}}$ and Melissa Strong, who emphasises Egan's experimental depiction of narrative time. ${ }^{\text {xxxii }}$ As distinct from both these aspects, the main argument of the current discussion is that Egan's linked stories are tantamount to fictional case studies in the elucidation of different vocational personalities. Since Maree suggests that much of the theoretical literature on career construction theory exists in the form of case studies, this means that the vocational dimension of the novel can be effectively illuminated when treated like them. ${ }^{\text {xxxii }}$

At the core of A Visit from the Goon Squad is the relationship between Bennie and Scotty, would-be musicians whose attempts at forming a band in the 1970s failed when they argued over a girl, Alice. By the twenty-first century, Bennie has succeeded in forging a successful career as a music producer whereas Scotty drops out of the industry altogether. In some senses, therefore, being an enabler rather than an artist represents for Bennie the kind of compromise discussed above in regard to the character Jules in The Interestings who feels meaningful fulfilment by creating opportunities for others rather than by becoming an artist herself. A substitutive or vicarious form of vocation, what might be termed vocation by proxy, is thus presented as the legitimate compensation for an earlier form of vocation and hence as a vocation in its own right. There is a direct model for this kind of vocation in the existing literature on career construction theory, when Savickas talks about a young woman who had been traumatised by witnessing her mother's suicide during her own infancy and subsequently became a hospice carer, a 'midwife for death.' xxxiv According to Savickas, helping others die well was a means by which she healed the pain she had experienced 
by being left powerless to help in the earlier situation, the memory of which thus helped her construct a vocational purpose.

An even clearer instance of an aspiration by proxy serving this constructivist function arises in the novel through Egan’s depiction of Bennie’s assistant Sasha, and her husband Drew. Drew has become a doctor as a compensatory mechanism for having failed to rescue his friend Rob, who had drowned himself in the East River during their student days out of apparent frustration at having spent years pretending to be Sasha's boyfriend for the benefit of her father, whereas in reality Sasha had chosen Drew. Chapter Twelve of A Visit from the Goon Squad is narrated in the form of a PowerPoint presentation, which partly emphasises Egan's commitment to experimenting in different media while also ironically commenting on them. ${ }^{\mathrm{xxxv}}$ Such presentations usually offer coherence, order and a near series of steps from the beginning of a project to its accomplishment. Yet the vocations portrayed throughout the novel refuse to adhere to such a near format, bristling discordantly with the smooth presentation slides of the PowerPoint and allowing a more nuanced understanding of the chaotic way in which vocations tend to be played out to emerge from the disjunction created. Thus Regina Schober has argued that the novel stages itself as the complementary 'other' of emerging forms of new media, thereby revealing an ambivalence about the relationship between technology and posthumanism that bespeaks a wider interplay between nostalgia for prior cultural forms and enthusiasm for the new. ${ }^{\text {xxxvi }}$

The PowerPoint presentation is chiefly dedicated to the lives of Drew and Sasha's children rather than those of Drew and Sasha themselves. This implies that the attempt at forming an aspiration by proxy represented by Drew’s decision to become a doctor and Sasha's to be a mother have come to fruition from the standpoint of the imagined future narrated in this way. Likewise Bennie’s career as a musical producer 
seems to offer him at least some form of vicarious accomplishment in his musical vision. On the other hand, as with Ethan in The Interestings, becoming commercially successful does not in itself bring Bennie happiness or a sense of purpose. When he and his wife Stephanie move to the affluent area of Crandale, Stephanie plays tennis with Kathy and other upper-class women whose lifestyle Bennie resents. His sexual relationship with Kathy is a form of violent revenge on her privilege and his frustrations.

Stephanie herself is a public relations executive employed in an agency run by the glamorous guru La Doll. But La Doll’s professional status suffers a dramatic downturn when several famous guests are scarred in an accident with boiling oil at a party she organised, and the public relations world begins to shun her. She only recuperates her career by improving the public image of a South American dictator, and the avenues to art, wealth and power which she had lost become accessible to her again.

Egan's portrayal of La Doll's route through the turbulent world of public relations is clearly intended to be both comical and ironic, but as with all forms of irony it also masks a serious point, a point that can again be extrapolated through comparison to an existing case study in career construction theory. In Career Counseling Savickas notes that in career interviews he often asks clients what fictional characters they ‘admire' because elucidating symbolic traits can be a useful way of clarifying vocational decisions. ${ }^{\text {xxvii }}$ He discusses the example of a student who could not decide what to do after graduation, and whose favourite fictional character was Wonder Woman. This of course could be interpreted in a number of different ways: it might have been that the student was interested in fighting for justice; or in redressing the balance in gender politics; or in becoming a political leader. In another sense, it might indicate that he was interested in working outdoors; or that he was attracted to creative 
elements such as design, costume or animation. At the extreme end, it could be seen as an indicator of an incipient bisexuality. Maree suggests that career counsellors must be careful to 'triangulate' such propositions alongside at least two other sources of information about each person before any real suggestion can be made. ${ }^{\text {xxviii }}$ In the end, what Savickas's student really admired was Wonder Woman's invisible plane; he went on to become a designer of stealth aircraft.

This example from Savickas demonstrates a profound tension in career construction theory between what benefits the individual and what is morally right in a wider transcendent sense. It might be that the business of practitioners of career construction is primarily to enhance the professional prospects of the individual, even if this means participating in an act that could be considered ethically compromised such as the construction of bomber aircraft. On the other hand, critical cultural theorists are more accustomed to considering moral questions about what constitutes the greater good. Thus Egan's depiction of a woman who performs public relations work for a dictator to salvage her own career is both comical and implicitly critical of an economy that deals so prevalently in images that it makes such a scenario necessary, no matter how morally repugnant. As with Ferris's sudden transition from the first-person to the second-person in the final pages of Then We Came to the End, Egan's portrayal of this conflict between individual advantage and collective moral right has the effect of implicating the individual, that is, the reader in the ethical question that is tacitly being asked. By this point, not only is career construction a useful way to illuminate the portrayal of dysfunctional vocations in fiction; but Egan’s fictional portrayal can also be used to open a new critical perspective on career construction theory itself.

\section{Conclusion}


The portrayal of vocations in crisis in the texts discussed here can effectively be elucidated using the work of career construction theorists. This in turn makes it possible to articulate a cultural response to the altered conditions in which people's working lives have unfolded since the onset of de-industrialisation and which changed further after the financial crash of 2007-08. As was argued at the outset of this paper, career construction theory has the scope to shed new light on questions of vocational behaviour, which have tended to be less widely discussed than professional careers or changes in the economy as such. This is in part because career construction theory itself developed largely in response to those changes. Since career construction depends on storytelling and forms of narration widely associated with literary practice, it is a fertile set of ideas for interpreting fictional portrayals of creative vocations.

Thus Savickas's idea of meta-reflection was applied to the discussion of Then We Came to the End to argue that Ferris's use of metafiction evokes a vocational consciousness that is implicitly critical of the prevailing socio-economic order. Holland's concept of vocational personality and McIlveen's related notion of Ipositions were then used to suggest that in The Blazing World, Hustvedt filters the fictive portrayal of the vocation of a female artist through numerous masks and personae in order to explore how far a vocational commitment has an impact upon a person's sense of selfhood. Ultimately the portrayal of different vocational personalities - which are all aspects of the same personality - is related to Hustvedt's critique of structures of cultural authority and economic power from a specifically feminist standpoint. By contrast, McIlveen's theoretical construct of an exo-theme was applied to analysis of Wolitzer's The Interestings. Wolitzer portrays the process by which people learn that fulfilling all their childhood dreams is rarely possible, so that the creation of a exo-theme, or meaningful compromise between what is imagined and what is possible 
becomes necessary over time. This is also in large part the feeling that emerges from $A$ Visit from the Goon Squad, which, when treated as a series of career construction case studies in the mould of Savickas or Maree, reveals the impossibility of fulfilling a nostalgic desire to return to an earlier state of affairs, and demonstrates instead that those protagonists are perpetually involved in re-making their vocations and hence themselves.

By exploring ways in which career construction theory can be used to critique the dominant ideology of the consumer economy in the twenty-first century, the discussion of these four novels has shown that career construction has the potential to raise critical questions about the relationship between individual vocation and collective commitment. Since the vocational guidance practice of career constructionism and the recent literary practice of representing unfulfilled vocations in fiction have common historical origins, the former can beneficially be used to enhance our understanding of the latter and vice versa. 
${ }^{\mathrm{i}}$ Larry Cochran, Career Counseling: A Narrative Approach (Thousand Oaks, CA: Sage, 1997), p. 14.

${ }^{\text {ii }}$ Cochran, p. 57.

iii See for example László Darvasi, 'Literature and the Global Economic Crisis’, Hungarian Quarterly, 49.192 (2008), pp. 51-55; Laura Fincher, 'The Un-real Deal: Financial Fiction, Fictional Finance, and the Financial Crisis', Journal of American Studies, 49.4 (2015), pp. 731-53; and Adam Weiner, How Bad Writing Destroyed the World: Ayn Rand and the Literary Origins of the Financial Crisis (New York: Bloomsbury, 2016).

${ }^{\text {iv }}$ E.g. Kirk Boyle and Daniel Mrozowski (eds.), The Great Recession in Fiction, Film, and Television: Twenty-First Century Bust Culture (Lanham, MD: Lexington Books, 2015).

v See Miranda Purves, 'Lionel Shriver’, Bloomberg Businessweek, 4486 (2016), pp. 70-71; and Molly Slavin, 'Ghost Stories, Ghost Estates: Melancholia in Irish Recession Literature’, C21 Literature: Journal of 21st-century Writings, 5.1 (2017), pp. 1-21.

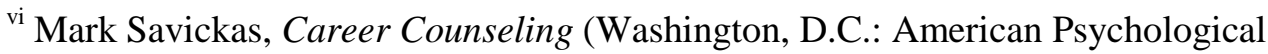
Association, 2011), p. 45.

vii See Hywel Dix, The Late-Career Novelist: Career Construction Theory, Authors and Autofiction (London: Bloomsbury, 2017), pp. 15-32.

viii Peter McIlveen and Wendy Patton, 'Dialogical Self: Author and Narrator of Career Life Themes', International Journal for Educational \& Vocational Guidance, 7.2 (2007), p. 71.

ix John Holland, Making Vocational Choices: A Theory of Vocational Personalities and Work Environments (Odessa, FL: Psychological Assessment Resources, 1997), p. 15.

${ }^{x}$ Peter McIlveen, 'Life Themes in Career Counselling’ in Mary McMahon and Mark Watson (eds.), Career Counseling and Constructivism: Elaboration of Constructs (New York: Nova, 2013), p. 73.

${ }^{x i}$ Kobus Maree, Counselling for Career Construction: Connecting Life Themes to Construct Life Portraits. Turning Pain into Hope (Rotterdam: Sense, 2013), p. 13.

xii Savickas, p. 15.

xiii See Katy Shaw, Crunch Lit (London: Bloomsbury, 2015). 
${ }^{\text {xiv }}$ Ruth Maxey, 'National Stories and Narrative Voice in the Fiction of Joshua Ferris', Critique: Studies in Contemporary Fiction, 57.2 (2016), p. 210.

${ }^{\mathrm{xv}}$ Alison Russell, 'The One and the Many: Joshua Ferris's Then We Came to the End', Critique: Studies in Contemporary Fiction, 59.3 (2018), p. 319.

xvi Joshua Ferris, Then We Came to the End (London: Penguin, 2008), p. 385.

${ }^{\text {xvii }}$ Raymond Williams, 'The Reader in Hard Times' in his Writing and Society (London: Verso, 1985).

xviii Fredric Jameson, The Political Unconscious (London: Methuen, 1981).

${ }^{\text {xix }}$ Ferris, p. 189.

${ }^{\mathrm{xx}}$ See Heike Schwarz, “"We have different selves over the course of a life, but even all at once”: The Multiple Self and Cultural Multiple Personality in Siri Hustvedt's The Blazing World' in Johanna Hartmann, Christine Marks and Hubert Zapf (eds.), Zones of Focused Ambiguity in Siri Hustvedt's Works (Berlin: Walter de Gruyter, 2016), pp. 389-407; Natalie Kon-Yu and Julienne Van Loon, 'Gendered Authorship and Cultural Authority in Siri Hustvedt's The Blazing World', Contemporary Women's Writing, 12.1 (2018), pp. 4966; and Ruby de Vos, 'The Monstrosity of the Female Artist in Dept. of Speculation, The Blazing World, and I Love Dick', Thamyris/ Intersecting, 32 (2018), pp. 180-200. ${ }^{x x i}$ Savickas, p.77.

xxii Jean Starobinski, The Idea of Nostalgia, trans. William S. Kemp. Diogenes, 14.54 (1966), pp. 81-103.

xxiii Maree, p. 34.

xxiv Siri Hustvedt, The Blazing World (London: Sceptre, 2014), p. 255.

${ }^{x x v}$ McIlveen, p. 74.

xxvi Ibid.

xxvii Meg Wolitzer, The Interestings (London: Vintage, 2014), p. 255.

xxviii Maree, p. 65.

${ }^{\text {xxix }}$ Svetlana Boym, The Future of Nostalgia (New York: Basic Books, 2001).

${ }^{\mathrm{xxx}}$ Wolitzer, p. 455.

${ }^{\text {xxxi }}$ Katherine D. Johnston, 'Metadata, Metafiction, and the Stakes of Surveillance in Jennifer Egan's A Visit from the Goon Squad', American Literature, 89.1 (2017), pp. 155-84. 
xxxii Melissa J. Strong, 'Found time: Kairos in A Visit from the Goon Squad', Critique, 59.4 (2018), pp. 471-80.

xxxiii For examples see Maree, pp. 84-110.

xxxiv Savickas, p. 82.

${ }^{x x x v}$ Jennifer Egan, A Visit from the Goon Squad (Fremont, CA: Corsair, 2010), pp. 234-309.

${ }^{\text {xxxvi }}$ Regina Schober, 'Between Nostalgic Resistance and Critical Appropriation: Contemporary American Fiction on/ of the Information Age and the Potentials of (Post)Humanist Narrative', Amerikastudien, 61.3 (2016), pp. 359-79.

xxxvii Savickas, p. 57.

xxxviii Maree, p. 77. 